\title{
The Effect of Leadership and Job Pressure on Organizational Performance through Organizational
} Commitments on PT. NUSATAMA BERKAH

\section{Dwi Wahyu Wibowo}

Student Master of Management

Universitas Krisnadwipayana

Email: dwiwahyu oke@yahoo.co.id

\author{
Abdul Rivai \\ Associate Professor \\ Universitas Krisnadwipayana \\ Email: abdulrivai@unkris.ac.id \\ Bongsu Saragih \\ Lecturer \\ Universitas Krisnadwipayana \\ Email: Bongsu.saragih@gmail.com
}

Abstract

\begin{abstract}
This study aims to determine the effect of leadership and job pressure on organizational performance simultaneously, the influence of leadership on organizational performance partially, the influence of work pressure on organizational performance partially, the influence of organizational commitment on organizational performance partially, the influence of leadership on organizational performance through organizational commitment and the effect of work pressure on organizational performance through organizational commitment. The research was conducted at PT. Nusatama Berkah. Sampling uses accidental samples involving 66 employees. Data analysis using path analysis.

Based on the data analysis, it is known that leadership variables and job pressure affect the performance of the organization simultaneously. Leadership variables influence partially on organizational performance. Job stress variables partially influence organizational performance. Organizational commitment variables affect organizational performance partially. The direct influence of leadership on organizational performance is smaller compared to indirect effects through organizational commitment. The direct effect of work pressure on organizational performance is smaller than through organizational commitment. In this case, the organizational commitment variable is an intervening variable.
\end{abstract}

\section{Keywords: leadership, work pressure, organizational commitment, organizational performance}

\section{INTRODUCTION}

Every organization needs organizational performance. Organizational performance is a description of the achievement of an organization in the implementation of activities, programs, policies to realize the vision, mission, and goals of the organization that have been previously set.

Organizational performance is influenced by various factors such as leadership, work pressure, and organizational commitment. Fiedler (1967) explained that leadership is the ability to provide direction and coordination to subordinates in achieving organizational goals, as well as willingness to be the main person in charge of the activities of the groups they lead. leadership includes the process of influencing in determining organizational goals, motivating followers' behavior to achieve goals, influencing the interpretation of the events of their followers, organizing and activities to achieve goals, maintaining cooperative and group work relations, obtaining support and cooperation from people outside the group or organization.

Another factor that influences organizational performance is work pressure. Job pressure is an adaptive response, connected by characteristics and/or individual psychological processes, which is a consequence of any 


\section{(c) Center for Promoting Education and Research}

WWW.cpernet.org

external action, situation, or event that places special psychological and/or physical demands on a person. Job pressure occurs because of an imbalance between the personality characteristics of employees and the characteristics of aspects of their work and can occur in all work conditions. Organizational commitment also influences organizational performance. Organizational commitment is a condition in which an employee sided with a particular organization and its goals and desires to maintain membership in the organization. So, high job involvement means taking sides with a particular individual's work, while high organizational commitment means taking sides with the organization that recruits the individual. Commitments are aimed at attitudes that reflect the extent to which an individual knows and is bound to his organization. A person who has a high commitment is likely to see himself as a true member of the organization. Whereas according to Kreitner and Kinicki (2014) that organizational commitment reflects the degree to which a person recognizes an organization and is bound to its goals.

\section{LITERATURE REVIEW}

\section{Leadership}

Fiedler (1967) explained that leadership is the ability to provide direction and coordination to subordinates in achieving organizational goals, as well as willingness to be the main person in charge of the activities of the groups they lead.

According to Rivai (2005:2) states that the definition of leadership broadly, includes the process of influencing in determining organizational goals, motivating followers' behavior to achieve goals, influencing interpretation of the events of followers, organizing and activities to achieve goals, maintain relationships cooperation and group work, the acquisition of support and cooperation from people outside the group or organization.

According to Hasibuan (2007: 170) "Leadership is the way a leader influences the behavior of subordinates to work together and work effectively and efficiently to achieve organizational goals". According to Hanafi (2002), there are five leadership functions, namely:

1. The direction function, namely how leaders in managing the organization effectively by determining the strategies and tactics that are prepared by the leadership to achieve the goals to be achieved and by optimizing the use of all available facilities.

2. Function as a spokesperson, this function requires a leader to act as a liaison between the organization and other interested parties such as shareholders, suppliers, suppliers, financial institutions and related government agencies.

3. Function as a communicator, which is a function as a communicator that emphasizes the ability to communicate goals.

4. Function as a mediator to overcome and resolve problems in the organization.

5. The function as an integrator is the attitude to prevent behavior and actions that are compartmentalized.

Disagreements about the definition of leadership are based on the fact that leadership involves complex interactions between leaders, followers, and situations. Most definitions of leadership reflect the assumption that leadership involves a process of social influence that is intentionally carried out by someone against others to structure activities and relationships within a group or organization (Yukl, 2:1994).

\section{Pressure}

Formally, stress is "an adaptive response, connected by characteristics and/or individual psychological processes, which is a consequence of any external action, situation, or event that places a particular psychological and/or physical demands on a person.

Job stress is stress due to an imbalance between the personality characteristics of employees and the characteristics of aspects of their work and can occur in all work conditions. Quick and Quick (1984) categorize stress types into two, namely: 
1. Eustress, which is the result of a response to stress that is healthy, positive, and constructive. These include the well-being of individuals and organizations that are associated with growth, flexibility, adaptability and high levels of performance.

2.Distress, which is the result of a response to stress that is unhealthy, negative, and destructive (destructive). These include individual and organizational consequences such as cardiovascular disease and high absenteeism, which is associated with illness, decline, and death.

Stressors are environmental factors that cause stress. In other words, stressors are a prerequisite for experiencing a stress response. The picture above shows four main types of stressors, namely:
1. Individual-level
2. Group level
3. Level of organization
4. Outside the organization

\section{Organizational Commitment}

According to Robbins and Judge (2008:100) organizational commitment is a condition in which an employee sided with a particular organization and its goals and desires to maintain membership in the organization. So, high job involvement means taking sides with a particular individual's work, while high organizational commitment means taking sides with the organization that recruits the individual.

Whereas according to Moorhead and Griffin (2013:73) organizational commitment is an attitude that reflects the extent to which an individual knows and is bound to his organization. A person who has a high commitment is likely to see himself as a true member of the organization. Whereas according to Kreitner and Kinicki (2014:165) that organizational commitment reflects the degree to which someone recognizes an organization and is bound to its goals.

It can be concluded that organizational commitment is an individual psychological state that is associated with strong beliefs, beliefs, and acceptance of organizational goals and values, a strong willingness to work for the organization and the degree to which he wants to be a member of the organization.

\section{Organizational Performance}

The term raw performance can be interpreted as an assessment to find out the final goals to be achieved by individuals, groups, and organizations. In this sense performance is a tool that can be used to measure achievement levels or group and individual policies. Some opinions about performance were also expressed by several experts as follows:

According to Keban(2004) performance is a translation of performance which is often interpreted as "appearance", "demonstration" or "achievement". This also agrees with what Mangkunegara said (2008:67) that the term performance originates from the word job performance or actual performance, namely work performance or achievement to be achieved. actors, namely:

According to Keban (2004:183), the achievement of results (performance) can be assessed according to the

1. Individual performance that describes how far someone has carried out their main tasks so that they can provide results set by the group or agency.

2. Group performance, which describes how far someone has carried out their main tasks so that they can provide the results set by the group or agency.

3. Organizational performance, which describes how far one group has carried out all the main activities to achieve the vision and mission of the institution.

4. Program performance, which is related to how far the activities in the program have been implemented so that they can achieve the objectives of the program. 
Performance is a description of the level of achievement of an activity/program/policy in realizing the goals, objectives, mission, and vision of the organization contained in the strategic planning of an organization (Mahsun, 2006: 25). Performance is a set of outputs (outcomes) produced by the implementation of certain functions over some time (Tangkilisan, 2003:109).

Organizational performance is an overview of the work of the organization in achieving its objectives which of course will be influenced by the resources possessed by the organization. The resources in question can be physical such as human or non-physical resources such as regulations, information, and policies, so to better understand the factors that can influence an organization's performance. The concept of organizational performance also illustrates that every public organization provides services to the community and can measure its performance by using existing performance indicators to see whether the organization has carried out its duties well and to know whether the objectives have been achieved or not.

\section{RESEARCH METHODS}

\section{Object of Research}

The research was conducted at PT. Nusatama Berkah in Bekasi. This company provides heavy equipment services, installation, and supply of other company goods.

\section{Research Population and Samples}

The population is a generalization area consisting of objects/subjects that have certain quantities and characteristics determined by researchers to be studied and conclusions drawn (Sugiyono,2011). The sample is a partial withdrawal of the population to represent the entire population (Surakhmad,1990). The total number of employees is 66 people. This amount is the total number of employees in the company. This sampling technique is also called the saturated sampling method. In this sampling method, the entire population was involved in sampling.

\section{Data Collection Technique}

To obtain concrete and objective data, research must be conducted on the problem under study, while the steps that the researcher takes in collecting data are primary data. Primary data is data obtained directly from the object of research. In this case, the primary data obtained from the field research is a method of data collection conducted by direct research on the object of research in question.

\section{RESEARCH RESULTS AND DISCUSSION}

\section{Effect of Leadership and Job Pressure on Organizational Performance}

Linear analysis models can be seen based on calculations using the SPSS program as follows.

Table 1. Results of the first equation analysis

\begin{tabular}{|c|c|c|c|c|c|}
\hline \multirow[t]{2}{*}{ Model } & \multicolumn{2}{|c|}{$\begin{array}{c}\text { Unstandardized } \\
\text { Coefficients }\end{array}$} & \multirow{2}{*}{$\begin{array}{c}\begin{array}{c}\text { Standardized } \\
\text { Coefficients }\end{array} \\
\text { Beta }\end{array}$} & \multirow[t]{2}{*}{$\mathrm{t}$} & \multirow[t]{2}{*}{ Sig. } \\
\hline & B & Std. Error & & & \\
\hline 1 (Constant) & 16,575 & 2,964 & & 5,592 &, 000 \\
\hline LEADERSHIP & ,706 & ,133 & ,441 & 5,302 &, 000 \\
\hline PRESSURE & ,561 & ,084 & ,557 & 6,693 & ,000 \\
\hline
\end{tabular}

a. Dependent Variable: PERFORMANCE

Based on the table above, simultaneous structural equations: $\mathrm{Y}=0.441 \mathrm{X} 1+0.557 \mathrm{X} 2$

The calculated $\mathrm{F}$ value can be obtained from the following table 
Table 2. F values for simultaneous persistence calculations

\begin{tabular}{|ll|r|r|r|c|c|}
\hline & Model & Sum of Squares & \multicolumn{1}{|c|}{ df } & Mean Square & F & Sig. \\
\hline 1 & Regression & 1280,029 & 2 & 640,015 & 42,285 &, $000^{\mathrm{b}}$ \\
& Residual & 953,562 & 63 & 15,136 & & \\
& Total & 2233,591 & 65 & & & \\
\hline
\end{tabular}

a. Dependent Variable: PERFORMANCE

b. Predictors: (Constant), PRESSURE, LEADERSHIP

Based on the table above it is known that the value of $\mathrm{f}$ count is 42.285 and significance is 0.00 . This value is smaller than 0.05. This means that leadership variables and job pressure affect the organization's performance simultaneously. The magnitude of the influence of independent variables on the dependent variable can be seen from the value of $\mathrm{r}$ squared as follows.

Table 3. The value of $r$ squared first regression model

\begin{tabular}{|l|r|r|r|r|r|}
\hline Model & \multicolumn{1}{|c|}{$\mathrm{R}$} & R Square & \multicolumn{1}{|c|}{$\begin{array}{c}\text { Adjusted R } \\
\text { Square }\end{array}$} & $\begin{array}{c}\text { Std. Error of } \\
\text { the Estimate }\end{array}$ & Durbin-Watson \\
\hline 1 &, $757^{\mathrm{a}}$ &, 573 &, 560 & 3,89049 & 1,292 \\
\hline
\end{tabular}

a. Predictors: (Constant), PRESSURE, LEADERSHIP

b. Dependent Variable: PERFORMANCE

Based on the table above, it is known that the value of $\mathrm{r}$ squared is $57.3 \%$, meaning that the leadership variables and work pressure affect the organizational performance by $57.3 \%$ while the rest is influenced by other variables which are not included in the equation model.

\section{Analysis of Influence Leadership on Organizational Performance Partially}

The results of the analysis of the influence of leadership on organizational performance partially can be seen in the following table.

Table 4. Results of analysis of the second regression equation

\begin{tabular}{|rl|r|r|r|r|r|}
\hline \multirow{2}{*}{ Model } & \multicolumn{2}{|c|}{$\begin{array}{c}\text { Unstandardized } \\
\text { Coefficients }\end{array}$} & $\begin{array}{l}\text { Standardized } \\
\text { Coefficients }\end{array}$ & \multirow{2}{*}{$\mathrm{t}$} & \multirow{2}{*}{ Sig. } \\
\cline { 2 - 5 } & \multicolumn{1}{|c|}{ B } & Std. Error & \multicolumn{1}{c|}{ Beta } & & \\
\hline 1 & (Constant) & 26,122 & 3,372 & & 7,746 &, 000 \\
& LEADERSHIP &, 831 &, 171 &, 519 & 4,859 &, 000 \\
\hline
\end{tabular}

a. Dependent Variable: PERFORMANCE

The structural equation from the data above: $\mathrm{Y}=0.519 \mathrm{X} 1$

Based on the table of analysis results above, it is known that the leadership coefficient is 0.519 . $T$ value of 4.859. The significance value of 0.00 . This significance value is smaller than 0.05 . This means that leadership variables influence the performance of the organization partially. The magnitude of the influence of leadership on organizational performance can be seen in the following table.

Table 5. Value of $\mathbf{r}$ squared of the second equation

\begin{tabular}{|r|r|r|r|r|}
\hline Model & \multicolumn{1}{|c|}{$\mathrm{R}$} & R Square & Adjusted R Square & Std. Error of the Estimate \\
\hline 1 &, $519^{\mathrm{a}}$ &, 270 &, 258 & 5,04916 \\
\hline
\end{tabular}

a. Predictors: (Constant), PERFORMANCE 
Based on the table above, it can be seen that the value of $r$ squared is 0.270 . This means that the influence of leadership variables on performance is $27.0 \%$ and the rest is influenced by other variables which are not included in the equation model.

\section{Analysis of the Effect of Job Pressure on Organizational Performance Partially}

The results of the analysis of the influence of work pressure on performance partially can be seen in the following table.

Table 6. Results of the analysis of the third regression equation

\begin{tabular}{|rl|r|r|r|r|r|}
\hline \multirow{2}{*}{ Model } & \multicolumn{2}{|c|}{$\begin{array}{c}\text { Unstandardized } \\
\text { Coefficients }\end{array}$} & $\begin{array}{c}\text { Standardized } \\
\text { Coefficients }\end{array}$ & \multirow{2}{*}{$\mathrm{t}$} & \multirow{2}{*}{ Sig. } \\
\cline { 2 - 5 } & \multicolumn{1}{|c|}{ B } & Std. Error & \multicolumn{1}{c|}{ Beta } & & \\
\hline \multirow{2}{*}{1} & (Constant) & 28,916 & 2,190 & & 13,207 &, 000 \\
& PRESSURE &, 623 &, 099 &, 619 & 6,298 &, 000 \\
\hline
\end{tabular}

a. Dependent Variable: PERFORMANCE

The structural equation from the data above: $\mathrm{Y}=0.619 \mathrm{X} 2$

Based on the table of analysis results above, it is known that the coefficient of work pressure is 0.619 . T value of 6.298. The significance value of 0.00 . This significance value is smaller than 0.05 . This means that the work pressure variable partially affects organizational performance. The magnitude of the influence of work pressure on organizational performance can be seen in the following table.

Table 7. Value of $r$ squared third equation

\begin{tabular}{|l|r|r|r|r|}
\hline Model & R & R Square & Adjusted R Square & Std. Error of the Estimate \\
\hline 1 &, $619^{\mathrm{a}}$ &, 383 &, 373 & 4,64190 \\
\hline
\end{tabular}

a. Predictors: (Constant), PRESSURE

Based on the table above, it can be seen that the value of $r$ squared is 0.383 . This means that the influence of job pressure variables on organizational performance is $38.3 \%$ and the rest is influenced by other variables which are not included in the equation model.

\section{Analysis of the Effect Organizational Commitment to Organizational Performance Partially}

The results of the analysis of the influence of work organization commitment to performance partially can be seen in the following table.

Table 8. Results of the analysis of the fourth regression equation

\begin{tabular}{|l|r|r|r|r|r|}
\hline \multirow{2}{*}{ Model } & \multicolumn{2}{|c|}{ Unstandardized Coefficients } & $\begin{array}{l}\text { Standardized } \\
\text { Coefficients }\end{array}$ & \multirow{2}{*}{$\mathrm{t}$} & \multirow{2}{*}{ Sig. } \\
\cline { 2 - 4 } & \multicolumn{1}{|c|}{$\mathrm{B}$} & Std. Error & \multicolumn{1}{c|}{ Beta } & & \\
\hline 1 (Constant) & 9,161 & 2,597 & & 3,527 &, 001 \\
COMMITMENT &, 799 &, 062 &, 849 & 12,872 &, 000 \\
\hline
\end{tabular}

a. Dependent Variable: PERFORMANCE

The structural equation from the data above: $\mathrm{Y}=0.849 \mathrm{X} 3$

Based on the table of results of the analysis above, it is known that the coefficient of organizational commitment is 0.849 . $\mathrm{T}$ value is 12,872 . The significance value of 0.00 . This significance value is smaller than 0.05 . This means that the organizational commitment variable affects organizational performance partially. The magnitude of the influence of organizational commitment on organizational performance can be seen in the following table.

Table 9. Value of $r$ squared four equation

\begin{tabular}{|l|r|r|r|r|}
\hline Model & \multicolumn{1}{|c|}{ R } & R Square & Adjusted R Square & Std. Error of the Estimate \\
\hline 1 &, $849^{\mathrm{a}}$ &, 721 &, 717 & 3,11832 \\
\hline
\end{tabular}

a. Predictors: (Constant), COMMITMENT 
Based on the table above it can be seen that the value of $r$ squared is 0.721 . This means that the influence of organizational commitment variables on organizational performance is $72.1 \%$ and the rest is influenced by other variables which are not included in the equation model.

\section{Analysis of Influence Leadership on Organizational Performance through Organizational Commitment}

Based on the partial path analysis above, it can be described as follows. The analysis is an analysis of the path with the following sub-structure images.

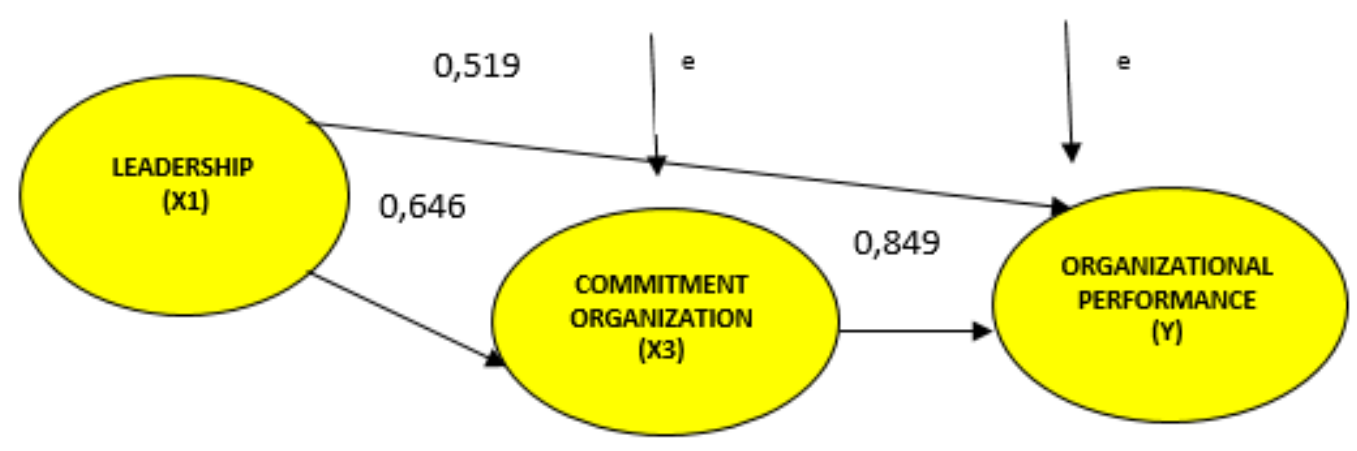

Figure 1. Analysis of the influence path X1 to Y through X3

The influence coefficient of leadership on work organization commitment can be seen in the following table.

Table 10. Effect of leadership on work organization commitment

\begin{tabular}{|c|c|c|c|c|c|}
\hline \multirow[t]{2}{*}{ Model } & \multicolumn{2}{|c|}{$\begin{array}{l}\text { Unstandardized } \\
\text { Coefficients }\end{array}$} & \multirow{2}{*}{$\begin{array}{c}\begin{array}{c}\text { Standardized } \\
\text { Coefficients }\end{array} \\
\text { Beta }\end{array}$} & \multirow[t]{2}{*}{$\mathrm{t}$} & \multirow[t]{2}{*}{ Sig. } \\
\hline & $\mathrm{B}$ & Std. Error & & & \\
\hline $\begin{array}{ll}1 & \text { (Constant) } \\
& \text { LEADERSHIP }\end{array}$ & $\begin{array}{r}20,064 \\
1,099\end{array}$ & $\begin{array}{r}3,199 \\
, 162\end{array}$ & 646, & $\begin{array}{l}6,272 \\
6,774\end{array}$ & $\begin{array}{l}, 000 \\
, 000\end{array}$ \\
\hline
\end{tabular}

a. Dependent Variable: COMMITMENT

Based on the picture above it can be seen that the influence of leadership on organizational performance is 0.519. The influence of leadership on performance through organizational commitment is $0.646 \times 0.849=0.548$. In this case, the indirect effect is greater than the direct effect so that it can be said that the variable work organizational commitment is an intervening variable.

\section{Analysis of the Effect of Job Pressure on Organizational Performance through Organization Commitments}

Based on the partial path analysis above, it can be described as follows. The analysis is an analysis of the path with the following sub-structure images.

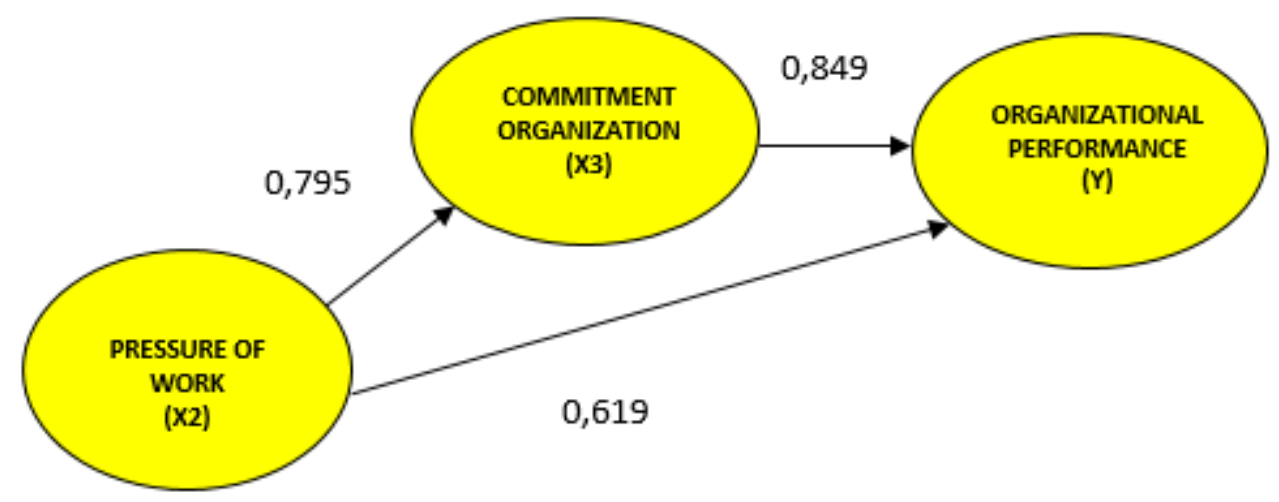

Figure 2. Analysis of the influence of X2 on Y through X3 
Job pressure coefficient value on work organization commitment can be seen in the following table.

Table 11. Coefficient of influence of work pressure on work organization commitment

\begin{tabular}{|rl|r|r|r|r|r|}
\hline \multirow{2}{*}{ Model } & \multicolumn{2}{|c|}{$\begin{array}{c}\text { Unstandardized } \\
\text { Coefficients }\end{array}$} & $\begin{array}{c}\text { Standardized } \\
\text { Coefficients }\end{array}$ & \multirow{2}{*}{$\mathrm{t}$} & \multirow{2}{*}{ Sig. } \\
\cline { 3 - 5 } & \multicolumn{1}{|c|}{ B } & Std. Error & Beta & & \\
\hline 1 & (Constant) & 23,193 & 1,797 & & 12,907 &, 000 \\
& PRESSURE &, 851 &, 081 &, 795 & 10,475 &, 000 \\
\hline
\end{tabular}

a. Dependent Variable: COMMITMENT

Based on the picture above, it can be seen that the direct effect of work pressure on organizational performance is 0.619 . While the effect of work pressure on organizational performance through organizational commitment is $0.795 \times 0.849=0.675$. In this case, the direct effect is smaller than the indirect effect so that it can be said that the variable organizational commitment is an intervening variable.

\section{CONCLUSIONS AND RECOMMENDATIONS}

\section{Conclusion}

Leadership variables and work pressure influence the performance of the organization simultaneously. The value of $\mathrm{f}$ count is 42.285 and significance is 0.00 . This value is smaller than 0.05 . The value of $\mathrm{r}$ squared is $57.3 \%$, which means that the leadership variables and work pressure affect organizational performance by $57.3 \%$ while the rest is influenced by other variables which are not included in the equation model.

Leadership variables influence partially on organizational performance. T value of 4.859 . The significance value of 0.00 . This significance value is smaller than 0.05 . The value of $r$ squared is 0.270 . This means that the influence of leadership variables on performance is $27.0 \%$ and the rest is influenced by other variables which are not included in the equation model.

Job stress variables partially influence organizational performance. T value of 6.298 . The significance value of 0.00 . This significance value is smaller than 0.05 . The value of $r$ squared is 0.383 . This means that the influence of job pressure variables on organizational performance is $38.3 \%$ and the rest is influenced by other variables which are not included in the equation model.

Organizational commitment variables affect organizational performance partially. $\mathrm{T}$ value is 12,872 . The significance value of 0.00 . This significance value is smaller than 0.05 . The value of $r$ squared is 0.721 . This means that the influence of organizational commitment variables on organizational performance is $72.1 \%$ and the rest is influenced by other variables which are not included in the equation model.

The influence of leadership on organizational performance is 0.519 . The influence of leadership on performance through organizational commitment is $0.646 \times 0.849=0.548$. In this case, the indirect effect is greater than the direct effect so that it can be said that the variable work organizational commitment is an intervening variable.

The direct effect of work pressure on organizational performance is 0.619 . While the influence of work pressure on organizational performance through organizational commitment is $0.795 \times 0.849=0.675$. In this case, the direct effect is smaller than the indirect effect so that it can be said that the variable organizational commitment is an intervening variable.

\section{Recommendations}

Ability to provide direction and coordination to subordinates in achieving goals and willingness to be the main person in charge of organizational activities (Hanafi, 2002) which is called leadership. Leadership needs to be improved by paying attention to the application of justice, giving suggestions, supporting the achievement of goals, always being able to increase the potential of resources and respect subordinates. 
Job pressure needs to be considered in improving organizational performance. This can be done by improving good communication, developing innovation and playing a more productive role.

Organizational commitment is also important to note by paying attention to affective commitment, ongoing commitment, and normative commitment. This increase in commitment needs to be increased by conducting motivational training for employees.

\section{References}

Amirullah, dan Hanafi, Rindyah. 2002. Pengantar Manajemen. Yogyakarta: Graha Ilmu.

Anwar Prabu Mangkunegara, 2008. Manajemen Sumber Daya Manusia Perusahaan, Cetakan Kedelapan. Bandung: PT Remaja Rosdakarya.

Fiedler, Fred E. A Theory of Leardership Effectiveness. New York: McGrawHill, 1967.

Hasibuan, Malayu. 2007. Manajemen Sumber Daya Manusia. Cetakan Kesembilan. Jakarta : PT. Bumi Aksara.

Keban, Y.T. 2004. Enam Dimensi Strategi Administrasi Publik: Konsep, Teori, dan Isu. Yogyakarta: Gava Media.

Kreitner, Robert dan Angelo Kinicki. 2014. Perilaku Organisasi. Edisi 9. Buku 1. Jakarta: Salemba Empat.

Mahsun, Mohamad. 2006. Pengukuran Kinerja Sektor Publik : Cetakan Pertama. Yogyakarta: Penerbit BPFEYogyakarta.

Moorhead dan Griffin. 2013. Perilaku Organisasi. Jakarta: Salemba Empat.

Quick, J.C., \& Quick, J.D. 1984. Organizational stress and preventive management. New York: McGraw-Hill. Robbins, Stephen P. dan Timothy A. Judge. 2008. Perilaku Organisasi Edisi ke-12, Jakarta: Salemba Empat.

Sugiyono. 2011. Metode Penelitian Kuantitatif, Kualitatif dan R\&D. Bandung: Afabeta.

Tangkilisan, Hessel Nogi S. 2003. Kebijakan Publik yang Membumi. Yogyakarta:Yayasan Pembaruan Aministrasi Publik Indonesia (YPAPI) \& Lukman Offset.

Veithzal Rivai, 2005, Manajemen Sumber Daya Manusia Untuk Perusahaan Dari Teori ke Praktik, Edisi 1, PT Raja Grafindo Persada, Jakarta.

Winarno Surakhmad, 1990, Pengantar penelitian Ilmiah, Tarsito, Bandung,

Yukl, Gary 1994. Leadership in Organisations. Terjemahan Jusuf Udayana. Kepemimpinan dalam Organisasi. Edisi 3. Penerbit Prenhallindo, Jakarta. 